\title{
Iz Islovarja
}

Islovar je spletni terminološki slovar informatike, ki ga objavlja jezikovna sekcija Slovenskega društva INFORMATIKA na naslovu http://www.islovar.org. Slovar je javno dostopen za vpoglede in vnašanje novih izrazov. Tokrat objavljamo izbor novejših izrazov, ki smo jih uredili v tem letu.

avtonómni robót $\mathrm{m}$ (angl. autonomous robot) robot, ki opravlja vedenje ali naloge $\mathrm{z}$ visoko stopnjo samostojnosti; prim. avtomatizacija vožnje, avtonomno vozilo

digitálni dvójnik -ega -a m (angl. digital twin) navidezna klonirana predstavitev fizičnega predmeta ali procesa $\mathrm{v}$ realnem času

elektrónski račún -ega -a m (angl. electronic invoice) račun, ki je bil izdan, poslan in prejet $\mathrm{v}$ elektronski obliki; prim. E-račun

É-račún -a m (angl. eInvoice) elektronski račun v Sloveniji, ki je v standardizirani obliki e-Slog; prim. elektronski račun

e-Slóg -a m (angl. e-Slog) standard, razvit v okviru Gospodarske zbornice Slovenije in usklajen z evropskim standardom za izdajanje elektronskih naročilnic, potrditev naročil, izdajanje dobavnic in računov

goljufíva téhnična podpóra -e -e -e ž (angl. technical support fraud) izvajanje lažne varnostne ali tehnične podpore $\mathrm{z}$ namenom pridobitve podatkov od žrtve

hektivízem -zma m (angl. hacktivism) hekersko gibanje, ki za promocijo svojih političnih stališč uporablja informacijsko-komunikacijsko tehnologijo hekerska dejanja za promocijo stališč ali doseganje političnih ciljev

informacíjska várnost -e -i ž (angl. information security) varnost podatkov in informacijskih sistemov pred zlorabo, uničenjem; sin. kibernetska varnost; prim. varnost informacijskega sistema, INFOSEC skupno delovanje ljudi, ukrepov, procesov in tehnologij za zaščito podatkov in informacijske komunikacijske opreme; sin. kibernetska varnost; prim. varnost informacijskega sistema, INFOSEC

kibernétska higiéna -e -e ž (angl. cyber hygiene) postopki, ki bi jih morali redno izvajati za zaščito računalniških sistemov in podatkov, npr. arhiviranje podatkov, preprečevanje nepooblaščenih dostopov, osveščanje uporabnikov

nabirálni robót -ega -a (angl. harvesting bot, harvesting robot) računalniški program za nabiranje naslovov; sin. nabiralni program

ôzko grlo -ega -a s (angl. bottleneck) komponenta z najmanjšo zmogljivostjo $\mathrm{v}$ celotnem sistemu

prestréznik gésel -a -- $\mathrm{m}$ (angl. password dumper) škodljiva programska koda, ki prestreza avtentikacijske podatke, npr. gesla; sin. kopirnik gesel, snemalnik gesel

protokól oddáljenega namízja -a -- -- m (angl. remote desktop protocol, $R D P$ ) protokol, ki uporabniku omogoča povezavo $\mathrm{z}$ drugim računalnikom prek omrežne povezave; sin. RDP; prim. navidezno zasebno omrežje

upárjenje -a s (angl. pairing) vzpostavljanje brezzične povezave med dvema združljivima enotama, npr. povezava Bluetooth, infrardeča povezava postopek, ki omogoča, da med seboj komunicirata dve napravi ali več naprav zaradi neposredne izmenjave podatkov, npr. pametna ura in telefon 